\title{
Parvovirus B19 and Pregnant Women: A Bibliographic Review
}

\author{
Majda Bouraddane ${ }^{1 *}$, Karima Warda ${ }^{1}$, Said Zouhair ${ }^{1,2}$ \\ ${ }^{1}$ Laboratory of Microbiology-Virology, Department of Biology, Faculty of Medicine and Pharmacy, University Cadi Ayyad, \\ Marrakech, Morocco \\ ${ }^{2}$ Laboratory of Bacteriology-Virology, Avicenne Military Hospital, Marrakech (HMA), Morocco \\ Email: ^bouraddane.majda@gmail.com
}

How to cite this paper: Bouraddane, M., Warda, K. and Zouhair, S. (2021) Parvovirus B19 and Pregnant Women: A Bibliographic Review. Open Journal of Obstetrics and Gynecology, 11, 1543-1564. https://doi.org/10.4236/ojog.2021.1111145

Received: June 24, 2021

Accepted: November 20, 2021

Published: November 23, 2021

Copyright (c) 2021 by author(s) and Scientific Research Publishing Inc. This work is licensed under the Creative Commons Attribution International License (CC BY 4.0).

http://creativecommons.org/licenses/by/4.0/ (c) (i) Open Access

\begin{abstract}
Primary infection with parvovirus B19 is an uncommon but serious and treatable cause of chronic anemia in immuno compromised hosts. Widely distributed, it is responsible for a wide range of clinical manifestations, the characteristics and outcome of which depend on the interaction between the viral properties and the physiological and immune status of the infected individuals. Infection during pregnancy can result in fetal anemia, abortion, and hydrops. Pregnancy does not appear to affect the course of the infection, but the infection may affect the pregnancy. The diagnosis of B19V can be made by serological and molecular investigation of the mother, fetus and newborn. In these conditions, it seemed necessary for us to answer in this article the various questions raised by the occurrence of a contagion and/or an infection with Parvovirus B19 during pregnancy. Our objective was to determine at first the nature and the main characteristics of Parvovirus B19 as well as its propagation during the pregnancy and to show its risk for the pregnant woman and her fetus. The importance of the subject is proven by the data on the spread and incidence of the virus. Worldwide, the focus on pregnancy is due to the additional potentially fatal effects on the fetus. This document covers the important aspects of a medical investigation: causes, symptoms, tests and diagnosis.
\end{abstract}

\section{Keywords}

Parvovirus B19, Pregnant Women, Clinical Manifestations, Fetal Death, Hydrops Fetalis

\section{Introduction}

Parvovirus B19 (PVB19) is one of the smallest viruses that are known to infect 
humans [1]. The clinical manifestations of B19V infection vary greatly and depend on age, hematologic and immunologic status. In immune competent individuals, the infection can be completely asymptomatic or can cause mild and self-limiting clinical manifestations such as erythema infectious or fifth disease during childhood, arthralgias and arthritis in adults, particularly in women [2] [3], chronic hemolytic anemia, and fetal death in utero or non-immune hydrops fetalis in pregnant women [4], due to the efficient replication of B19V in the erythroid progenitor cells [5].

In temperate climates, the infection may occur throughout the year, infection is most common in late winter or early spring [6]. During pregnancy, the virus is transmitted through exposure to infected respiratory droplets or blood products and vertically from mother to fetus [7] [8]. The vertical transmission of B19 occurs in about one-third of women infected [9]. The proportion of pregnant women susceptible to B19 infection ranges from $34 \%$ to $65 \%$ in various parts of the world. The incidence of seroconversion during pregnancy is estimated at between $1 \%$ and $1.5 \%$ in the endemic period, increasing to $13 \%$ in the epidemic period [10]. Non-immune women are most likely to be infected by young children [11].

Parvovirus infection of mothers is diagnosed using serologic or an immune assay enzyme B19 IgM and B19 IgG [12]. Viral DNA can be detected by polymerase chain reaction (PCR) and is considered to be the best indicator of infection in maternal, fetal blood, and amniotic fluid [13].

\section{Parvovirus B19: A Few Words of History}

Parvovirus B19 particles were first described in 1975 by Cossart, an Australian virologist working in London [1]. While checking normal blood donor's serum in an assay for hepatitis B she noticed an anomalous reaction in position 19 plate B [14]. This virus was successively called SPLV (Serum Parvovirus like Virus), Aurilac antigen (in France), Nakatani antigen (in Japan), then B19, number of the blood bag where it was isolated for the first time. This explains the name of the virus when there is no parvovirus B1 to B18. The pathogenic role of the virus was first identified in 1981 during erythroblastopenic attacks in patients with sickle cell disease. In 1983, it was recognized as the cause of erythema infectiosum or the 5th pediatric disease [15]. Subsequently, PVB19 infections have been linked to feto placental hydrops, fetal deaths in utero (MFIU) secondary to fetal anemia or myocardial involvement [16].

\section{Virology and Pathophysiology of B19V Infection}

\subsection{B19 Virus: Virology}

\subsubsection{Taxonomy}

Parvoviruses are common animal and insect pathogens. The Parvoviridae family is divided into two sub-groups: the Parvovirinae infecting vertebrate cells, and the Densoviridae infecting invertebrate cells (Table 1) [17]. The Parvovirinae are further sub-divided into three groups: 
Table 1. Excerpt of the current classification of the subfamily Parvovirinae, including proposed members of the genus Erythrovirus placed tentatively [17].

\begin{tabular}{|c|c|c|c|}
\hline Genus & Virus & Natural host (s) & Clinical spectrum \\
\hline \multirow[t]{4}{*}{ Parvovirus } & Aleutian mink disease virus & Mink, ferret, skunk, raccoon & $\begin{array}{l}\text { Immune complex disease and fetal } \\
\text { death }\end{array}$ \\
\hline & Canine parvovirus & Dog & Enteritis, myocarditis \\
\hline & Mice minute virus & Mouse & No known disease \\
\hline & Porcine parvovirus & Pig & Abortion, fetal death \\
\hline \multirow[t]{4}{*}{ Dependovirus } & Adeno-associated virus 1 to 6 & Human & No Known disease \\
\hline & Avian adeno-associated virus & Birds & No Known disease \\
\hline & Canine adeno-associated virus & Dog & No Known disease \\
\hline & Bovine adeno-associated virus & Cow & No Known disease \\
\hline \multirow[t]{6}{*}{ Erythrovirus } & Parvovirus & Human & $\begin{array}{l}\text { Erythma infectiosum, aplastic crisis, } \\
\text { arthritis, hysdrops fetalis, etc, }\end{array}$ \\
\hline & Parvovirus V9a & Human & Aplastic crisis? \\
\hline & Chipmunk parvovirus $^{\mathrm{a}}$ & Chipmunk & No Known disease \\
\hline & Simian parvovirus ${ }^{\mathrm{a}}$ & Cynomoglus monkeys & Anemia \\
\hline & Pig-tailed macaque parvovirus ${ }^{\mathrm{a}}$ & Pig-tailed macaques & Anemia and immunosuppression \\
\hline & Rhesus parvovirus ${ }^{\mathrm{a}}$ & Rhesus monkeys & Anemia \\
\hline
\end{tabular}

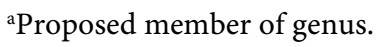

1) Genus Parvovirus that replicate autonomously.

2) Genus Dependovirus that needs helper viruses to replicate.

3) Genus Erythrovirus that need erythroid cells to replicate.

Parvovirus B19 belongs to the genus Erythrovirus.

\subsubsection{Morphology}

Parvovirus B19 is a small single-stranded DNA virus [18]. Parvovirus B19 is a non-enveloped, 22 to $26 \mathrm{~nm}$ icosahedral virus (Figure 1), is containing a single strand of DNA of approximately 5500 nucleotides. As with other parvoviruses, B19 employs overlapping reading frames to encode non-structural proteins and two capsid proteins. The B19 virion is an icosahedron consisting of 60 copies of the capsid proteins.

Most of the capsid consists of VP2, the major structural protein (molecular weight $58 \mathrm{kDa}$ ), with $5 \%$ or less of the larger VP1 protein, the minor protein ( 83 $\mathrm{kDa}$ ). Using genetic engineering techniques, the capsid proteins have been expressed in a variety of both mammalian and insect cell lines, where they self-assemble in the absence of DNA and form recombinant empty capsids [19]. VP1 is not required for capsid formation. The limited DNA content and the absence of a lipid envelope make this virus resistant to heat $\left(56^{\circ} \mathrm{C}\right.$ for $\left.60 \mathrm{~min}\right)$ and lipid solvents [20]. 

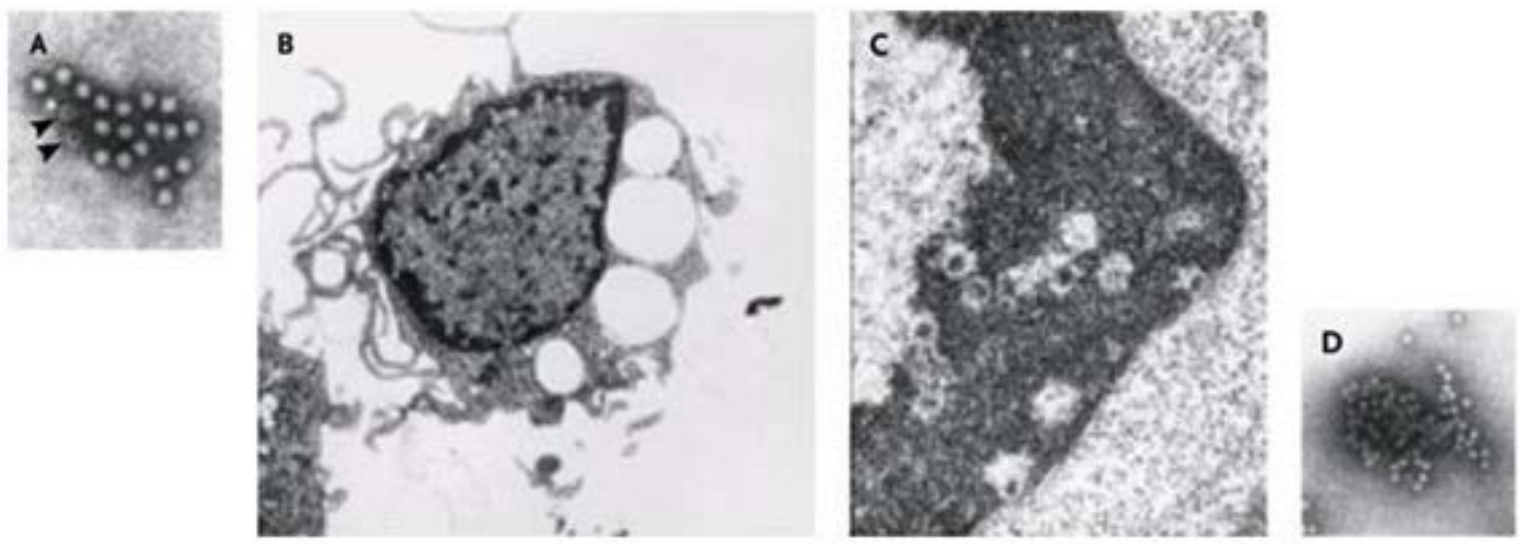

Figure 1. Transmission electron micrographs showing native parvovirus B19 in serum and cells and recombinant capsid [14]. Panel A shows symmetric, icosahedral particles, about $25 \mathrm{~nm}$ in diameter, and empty capsids (arrowheads) in serum from an infected. Panel B shows human erythroid progenitor cells infected in vitro with the virus; vacuoles and cytoplasmic pseudopods are present $(\times 10,000)$. In Panel $C$, which shows part of Panel B at higher magnification, marginated chromatin contains assembled capsids $(\times 100,000)$. Panel D shows empty recombinant parvovirus capsids produced in a baculovirus system $(\times 154,000)$.

\subsubsection{Genomic Structure and Organization}

As in most animal Parvoviruses, the B19 genome has two large open reading frames, with the single nonstructural protein (NS1) encoded by genes on the left side of the genome and the two capsid proteins (VP1 and VP2) by genes on the right side. The non-structural protein, from NS1, subserves multiple replicative functions and is cytotoxic to host cells [21]. The two structural proteins, viral protein 1 (VP1) and viral protein 2 (VP2), arise from alternative splicing so that VP1 is the same as VP2 except for an additional 226 amino acids at its amino-terminal [22] [23] [24] (Figure 2).

NS1 is a 671 amino acid long protein that has an MW of $\sim 75 \mathrm{kDa}$. NS1 contains two nuclear localization signals. NS1 contains a DNA binding and endonuclease domain at the $\mathrm{N}$-terminus.

In short, NS1 is a multifunctional protein and playsvarious roles during B19V infection [25]. VP2 is the predominant protein, comprising $95 \%$ of the virus capsid. VP1 is the same as VP2 except for additional 226 amino acids at its amino-terminal [26]. VP1makes up only $5 \%$ of the capsid, has its unique region external to the viral capsid itself, and is thought to be the main target of neutralizing antibodies. Sequence analysis reveals that NS1 is highly conserved, while VP1and VP2 shows greater variation [27]. Despite variations in VP1 and VP2, the antigens are commonly and successfully used in serologic tests.

$\mathrm{B} 19 \mathrm{~V}$ as a species is subdivided into three genotypes, the prototype genotype 1 , and two variant genotypes 2 and 3. At the nucleotide level, the diversity between genotype clusters is about $10 \%$, while the diversity within each genotype cluster is normally lower than $2 \%$ for genotype 1 and in the range $3 \%-10 \%$ for genotypes 2 and 3 [28]. All genotypes co-circulate, but with different frequencies and geographical distributions [29]. 


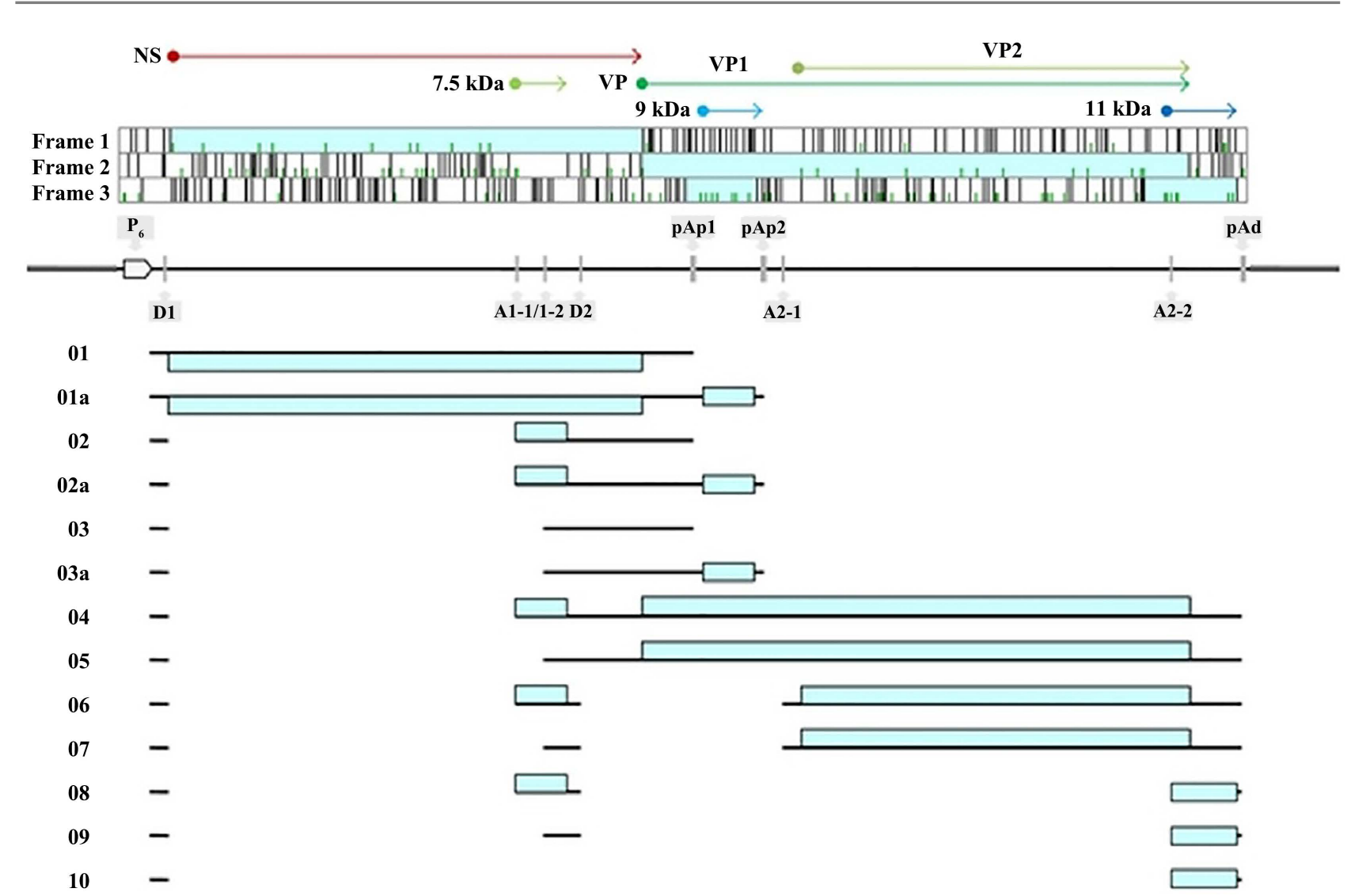

Figure 2. Schematic representation of B19V genome organization and functional mapping [24]. Top: open reading frames identified in the positive strand of genome; arrows indicate the coding regions for viral proteins positioned on the ORF map. Center: genome organization, with distinct representation of the terminal and internal regions and indication of the positions of promoter (P6), splice donor (D1, D2), splice acceptor (A1-1/2, A2-2/2), and cleavage-polyadenylation (pAp1, pAp2, and pAd) sites. Bottom: viral mRNAs species; black boxes indicate the exon composition and light boxes indicate the ORFs contained within mRNAs.

\section{Pathogenesis and Infection}

\subsection{Viral Life Cycle}

The only known natural host cell of parvovirus B19 is the human erythroid progenitor. Like other non enveloped DNA viruses the Parvovirus B19 life cycle includes the following stages: binding to host cell receptor, internalization, translocation of the genome to the host nucleus, DNA replication, RNA transcription, assembly of capsid, packing the genome, and cell lys is with release of the mature virion [3] (Figure 3). The $\mathrm{P}$ antigen on the red blood cell is a cellular receptor of the Parvovirus B19. However, all $\mathrm{P}$ antigen expressing cells are not permissive to B19V. Various other co-receptors like integrin $\alpha 5 \beta 1$ and antibody-mediated B19V entry routes are presumed to be involved in B19V entry [30].

\subsection{Pathogenesis and Immune Response}

After primary infection, mild symptoms of fever and general illness usually start after 6 - 10 days when viremia is highest. These symptoms will recede within a week [32] [33]. During the second week after infection, the viremia titer decreases, and IgM antibodies are detected. In the third week, the well known 


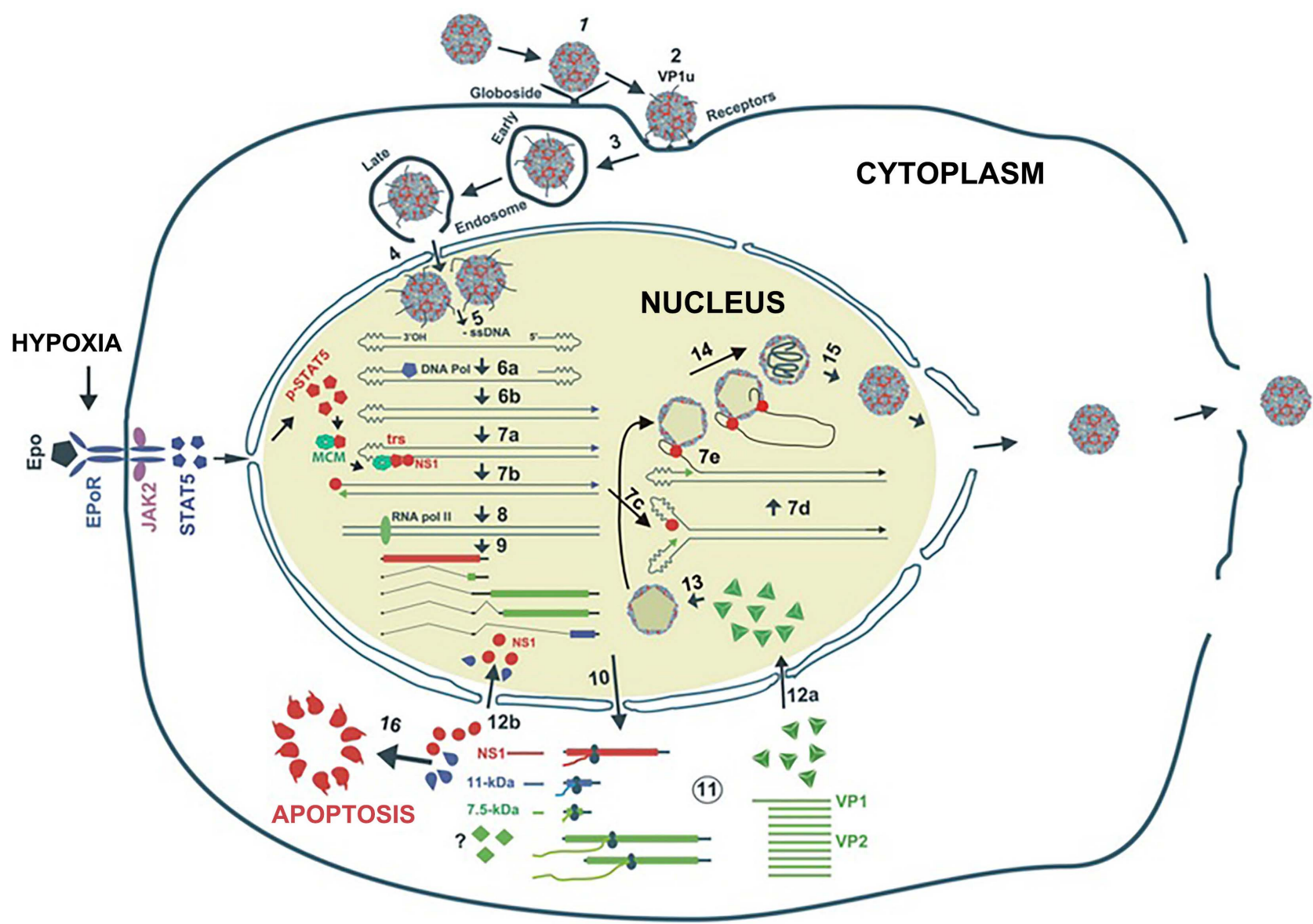

Human erythroid progenitors

Figure 3. Proposed model of B19V life cycle [31]. B19V infects human erythroid progenitor cells. The virus first interacts with globoside (Step 1) and undergoes a conformational change that exposes VP1u which subsequently binds an unknown co-receptor (Step 1). Thereupon, the virus is endocytosed and somehow escapes the lysosomal route and the virion un coats and releases the ssDNA genome (Step 3, 4). Using the 3' OH of the left ITR, the second strand is synthesized to form a functional origin of replication (Step 5). Next, EPO and hypoxia activates and increases pSTAT5. NS1 binding to NS1BE is critical for nicking ssDNA at trs and for helicase activity (step 6). The nicking creates a new 3' OH end to continue DNA replication that results into duplex replicative intermediate (Step 7). The dsDNA form also transcribes a single pre-mRNA that is processed into various mRNAs which are exported to cytoplasm for translation (Step 8). VP1/2 assembles into trimers to form capsids, which are transported back to the nucleus (Step 9). Through strand displacement, ssDNA is packaged into capsids, which probably requires NS1 (step 10). NS1 and $11-\mathrm{kDa}$ in the cytoplasm induce apoptosis (Step 11). After multiplication, the virion are released though cell lysis.

slapped cheeks and rash and the possible arthralgia occur, which coincides with an IgG antibody response [34]. These IgG antibodies can persist for years, while the IgM antibodies disappear after 6 - 10 weeks (Figure 4).

Recovery involves production of IgM antibody 10 to 12 days post infection, coinciding with a peak in virus level. IgM usually persists in serum samples for approximately 3 months but may be found for several months [35]. IgG antibody is detectable in volunteers about 2 weeks after inoculation and presumably persists for life and protects against secondary infections. IgA may also be detected and probably plays a role in protection against infection by the natural nasopharyngeal route [36]. 


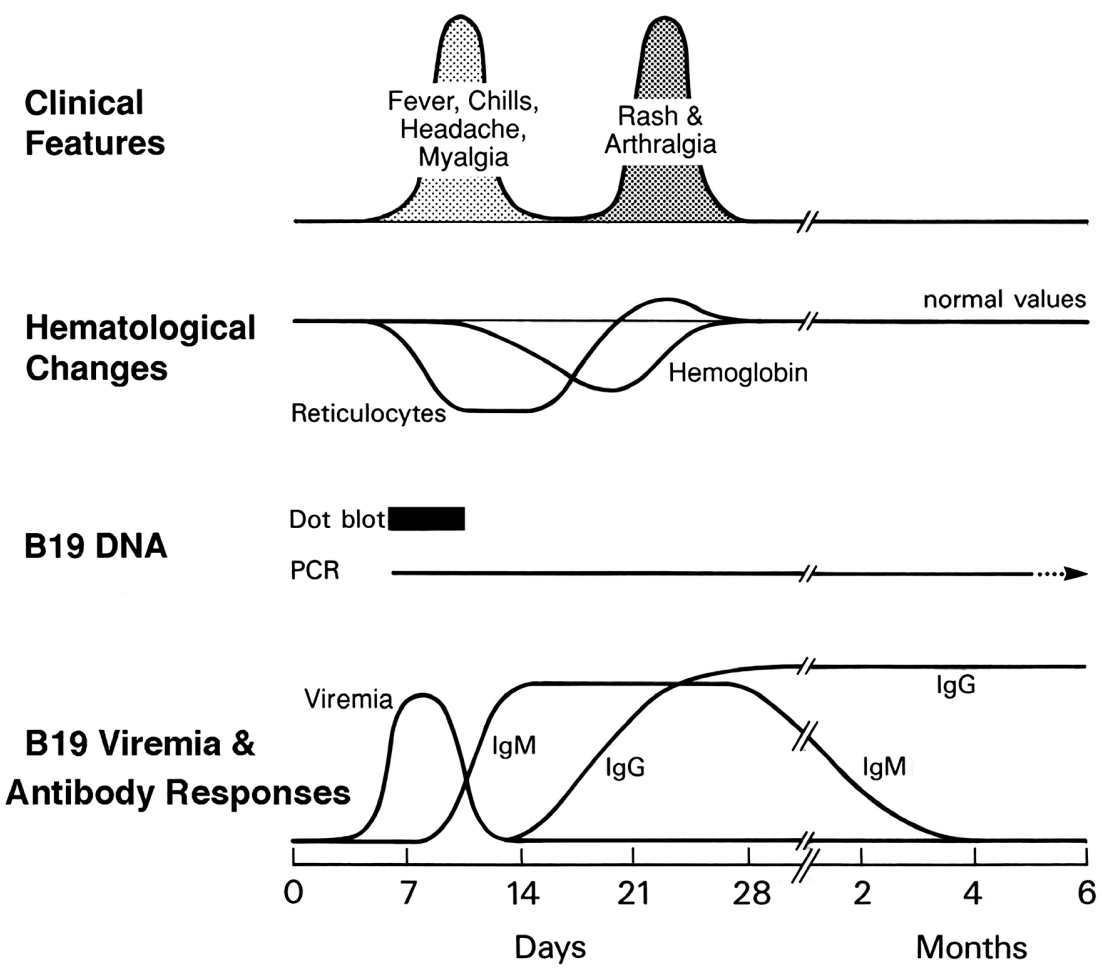

Figure 4. Virologic, immunologic, and clinical course following B19 infection [37].

\section{Parvovirus B19 and Autoimmunity}

Apart from rheumatoid arthritis (RA), B19 infection has been associated with the onset of numerous autoimmune disorders including systemic lupus erythematosus (SLE) [38], other connective tissue diseases, and systemic vasculatures. Although a few cases of erosive RA and SLE have been associated with B19 infection, the virus is probably an extremely rare cause of these diseases. Systemic vasculatures including, for example, Henoch-Schönlein purpura, periarteritis nods, and giant cell arthritis can occur after acute B19 infection [39]. The role of B19 in these disorders is not clear and in some cases, the infection may be a pure coincidence and in other cases, it can be a triggering or even a rare etiological factor [16].

\section{Parvovirus B19 infection in Pregnancy}

Acute parvovirus B19 infection is a risk for pregnant women. Since B19 infection occurs mainly during childhood, children represent a main source for virus transmission.

Human parvovirus B19 infection is widespread. Approximately $30 \%-50 \%$ of pregnant women are non immune, and vertical transmission is common following maternal infection in pregnancy. The magnitude of B19 has been studied in many developed countries [40] whereby the prevalence of specific B19 antibodies among pregnant women has been found to range from $1 \%$ to $5 \%$ with a transmission rate to the fetus of about $17 \%-33 \%$ [41].

Approximately $50 \%$ to $75 \%$ of women of reproductive age have developed 
immunity to parvovirus B19 [42] [43]. Without known exposure, about $1 \%$ to $3 \%$ of susceptible pregnant women will develop serologic evidence of infection in pregnancy [44], rising to over $10 \%$ in epidemic periods [45]. Where there is extensive opportunity for exposure to parvovirus B19, such as in a daycare center or school, it is estimated that $20 \%$ to $30 \%$ of susceptible women will develop an infection, while $50 \%$ of susceptible women exposed through household contacts will become infected [46]. The risk of infection in pregnant women with one child is 3 times more than nulliparous women, but this risk for women with three or more children is (are) 7, 5 times more. The other risk factors are working in the school, care centers, and other full stress jobs [47] [48].

\section{Fetal Effects of Parvovirus B19 Infection}

Primary PVB19 infection during pregnancy is potentially fatal to the fetus. Tran placental passage would occur at the time of the maximum peak of viremia following maternal contamination approximately one week. It is made possible by the expression of the $\mathrm{P}$ antigen on the surface of placental cells. The actual incidence of a fatal outcome for the fetus after parvovirus B19 infection remains difficult to establish. Vertical transmission of B19 has been shown to occur throughout pregnancy from 7 - 8 weeks of amenorrhea [49].

A relevant property of $\mathrm{B} 19 \mathrm{~V}$ is its ability to cross the placental barrier and infect the fetus [50]. When in the fetal circulation, the virus can infect erythroid progenitor cells, in liver and/or bone marrow depending on the gestational age, and can be detected in erythroid cells circulating in the vessels of several tissues, in endothelial placental cells as well as in the amniotic fluid.

Parvovirus B19 infection during pregnancy can cause severe anemia, non immune hydrops fetalis (NIHF), miscarriage, or even fetal death in utero [26] (Figure 5, Table 2). Intrauterine growth retardation, myocarditis, pleural effusion,
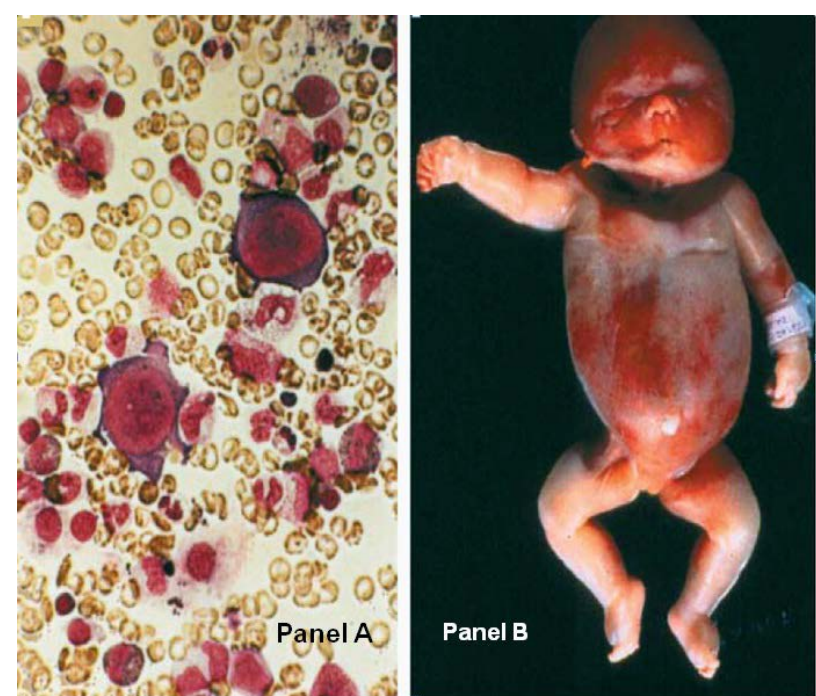

Figure 5. B19-associated hydrops fetalis [26]. Panel A shows a bone marrow aspirate with no mature erythroid precursors and with characteristic giant pronormoblasts. Panel B, hydrops fetalis is evident in an infant who was infected in utero in midtrimester. 
Table 2. General characteristics of studies reporting on outcome of fetuses with parvovirus B19 (PB19) infection included in systematic review.

\begin{tabular}{|c|c|c|c|c|c|}
\hline $\begin{array}{l}\text { Authors } \\
\text { (years) }\end{array}$ & Period of study & Country & Number of serum samples tested & Clinical Symptoms & Fetal Effects \\
\hline [53] & 1999-2004 & Sendai, Japan & Symptomatic Asymptomatic & $\begin{array}{l}\text { Facial Rasch }(51 \%) \\
(25 / 49) \\
\text { Most common } \\
\text { Infection } \\
\text { Children living } \\
\text { at home }\end{array}$ & $\begin{array}{l}\text { Hydrops fetalis et } \\
\text { fetal death } \\
7 \%(7 / 100) \\
>20 \text { weeks }\end{array}$ \\
\hline$[54]$ & $2005-2010$ & Bologna, Italy & 68 pregnant women had been & $\begin{array}{l}\text { Rash, fever and } \\
\text { polyarthralgia } \\
(79.3 \%) 23 / 29\end{array}$ & $\begin{array}{l}-10.2 \% \text { fetal deaths } \\
-11.9 \% \text { Hydrops fetalis }\end{array}$ \\
\hline [7] & 2004 & $\begin{array}{l}\text { Stuttgart, } \\
\text { Germany }\end{array}$ & 1018 & - & $\begin{array}{l}-6.3 \% \text { fetal deaths } \\
(64 / 1018) \\
-3.9 \% \text { Hydrops fetalis } \\
(40 / 1018)\end{array}$ \\
\hline [55] & $\begin{array}{c}1985-1988 \text { and } \\
1992-1995\end{array}$ & London & $\begin{array}{l}420 \text { pregnant women } \\
\text { with B19 infection }\end{array}$ & - & fetal loss averaged $9 \%$ \\
\hline$[56]$ & 2010 & Germany & $\begin{array}{l}236 \text { pregnant women } \\
\text { with B19 infection }\end{array}$ & - & $\begin{array}{l}\text { - } 18.8 \% \text { fetal loss }(8 / 236) \\
-23.6 \% \text { Hydrops fetalis } \\
(10 / 236)\end{array}$ \\
\hline [57] & 2014 & Paris, France & - & - & $\begin{array}{l}20 \text { cases of congenital } \\
\text { parvovirus B19 Infection } \\
(1 / 20) \text { (neonatal death) }\end{array}$ \\
\hline
\end{tabular}

pericardial effusion, pericardial effusion and brain involvement of the fetus may occur following infection with the virus, although, Parvovirus B19 is not related to congenital malformations [51].

The vertical transmission of B19V occurs in about one third of women infected during pregnancy. Consequently, in the first trimester, the risk of fetal loss is $5 \%-10 \%$, while in the second trimester is about $11 \%-12.5 \%$. It is considered that up to $20 \%$ non immune hydrops fetalis may be caused by B19V [52].

\section{Epidemiological Studies}

Infection with B19 is very common and cases of infection have been reported all over the world in all seasons. Parvovirus B19 is active worldwide with neither 
ethnical nor geographical boundaries, albeit with some regional differences [18].

Generally, seropositivity is lowest among young children, rises to around $50 \%$ at puberty [40], and in-creases further at lower rates throughout adulthood. Seropositivity is correlated with age, a history of transfusion, and urban residency.

Worldwide, the prevalence of PVB19 in pregnant women is variable, generally between $60 \%$ and $80 \%$, with lower prevalence in Asian regions [58].

Data on the seroprevalence of women susceptible to B19 infection in early pregnancy report a value of $26 \%$ to $43.5 \%$ in European countries and Japan [42] [48] [59].

In developing countries, the percentages are very similar, although the incidence and extent of infection have been studied in smaller population samples (Table 3).

Up to 2374 B19 infections occur annually in Japan among pregnant women. The risk of fetal death after infection is $9 \%$ during the first 20 weeks of pregnancy and up to 107 fetal deaths per year. Similarly, 2.9\% risk of fetal hydrops between 9 - 20 weeks of pregnancy or 21 cases are estimated each year [59].

\section{Laboratory Testing Options, Applications, and Interpretation}

Two circumstances lead to the diagnosis of parvovirus B19 infection in pregnant women: the occurrence of maternal clinical signs, mainly rash and arthritic manifestations, and the incidental finding of a fetoplacental hydrops [59]. The

Table 3. Prevalence of parvovirus B19 infection among normal and at risk pregnant women.

\begin{tabular}{|c|c|c|c|c|c|}
\hline $\begin{array}{l}\text { Reference } \\
\text { Number }\end{array}$ & Year & Country & $\begin{array}{c}\text { Total number of } \\
\text { serum samples tested }\end{array}$ & $\begin{array}{c}\text { Number of serum } \\
\text { samples infected by B19 }\end{array}$ & $\begin{array}{l}\text { Percentage } \\
\text { B19 positive }\end{array}$ \\
\hline$[60]$ & 2016 & Ardabil, Iran & 350 & 242 & $69.1 \%$ \\
\hline$[61]$ & 2014 & Azerbaijan, Iran & 86 & 65 & $75.6 \%$ \\
\hline$[62]$ & 2014-2015 & Mwanza, Tanzania & 258 & 142 & $55 \%$ \\
\hline$[63]$ & 2013 & Ogbomoso, Nigeria & 231 & 55 & $24 \%$ \\
\hline$[64]$ & 2012 & Sudan & 147 & 73 & $49.7 \%$ \\
\hline$[65]$ & 2011 & Tunisie & 404 & 307 & $76.2 \%$ \\
\hline [66] & 2007 & Cordoba, Spain & 42 & 27.7 & $66 \%$ \\
\hline [67] & $2007-2008$ & Tripoly, Libya & 150 & 100 & $66 \%$ \\
\hline$[68]$ & $2007-2008$ & Bialystok, Poland & 55 & 24 & $43 \%$ \\
\hline$[69]$ & $2008-2009$ & Khartoum state, Sudan & 500 & 287 & $57.4 \%$ \\
\hline [70] & $2003-2010$ & Milan, Italy & 37 & 29 & $78.3 \%$ \\
\hline [71] & 1999 & Kuwait & 1047 & 560 & $53.3 \%$ \\
\hline$[56]$ & $1999-2004$ & Sendai, Japan & 478 & 100 & $21 \%$ \\
\hline$[72]$ & $1999-2008$ & Oslo, Norway & 1349 & 832 & $61.7 \%$ \\
\hline$[73]$ & $1998-2000$ & Nijmegen, The Netherlands & 2567 & 1788 & $70 \%$ \\
\hline
\end{tabular}


search for parvovirus B19 in the laboratory is based on a multi parametric approach, combining the immunological search for specific antibodies and the molecular detection of viral DNA [74].

\subsection{Cell Culture}

The detection of viral particles in serum or bone marrow is not commonly used. In fact, PVB19 culture is only obtained by inoculating samples with fresh human marrow cells from a healthy donor. It is a cumbersome and expensive technique reserved for research [3].

\subsection{Serology}

A variety of methods can be used to detect parvovirus B19 antibodies (Table 4), and an international standard for B19 IgG assays has been developed and tested in collaborative studies [75] [76]. Numerous diagnostic kits are available, most of which are based on enzyme immunoassay, immuno fluorescence, or immuno blot techniques.

In general, IgM to B19 appears 7 to 10 days after infection, is followed within a few days by IgG, and remains positive for 2 to 4 months. In contrast, immuno compromised hosts may not develop antibodies, or IgM can develop but remain positive for months or years as an indicator of persistent infection, without development of IgG. A positive IgM test will indicate primary infection. If IgM and

Table 4. Parvovirus B19 serologic assays [76].

\begin{tabular}{|c|c|c|c|}
\hline Manufacturer & Method ${ }^{\mathrm{c}}$ & Antigen and Source & FDA Approved \\
\hline $\begin{array}{l}\text { Biotrin International } \\
\text { (Dublin Ireland) }\end{array}$ & Indirect IgG EIA and class-capture IgM EIA & Baculovirus-expressed VP2 ${ }^{\mathrm{a}}$ & Yes \\
\hline $\begin{array}{l}\text { Diasorin } \\
\text { (Saluggia, Italy) }\end{array}$ & $\begin{array}{l}\text { Indirect IgG and class-capture IgM } \\
\text { CLIA-Liaison platform }\end{array}$ & Baculovirus-expressed VP2 ${ }^{\mathrm{a}}$ & No \\
\hline $\begin{array}{l}\text { Denka Seiken } \\
\text { (Tokyo, Japan) }\end{array}$ & Indirect IgG and IgM EIA & Baculovirus-expressed VP1 and VP2 & No \\
\hline $\begin{array}{l}\text { Medac, Diagnostika } \\
\text { (Wedel, Germany) }\end{array}$ & Indirect IgG EIA and class-capture IgM EIA & Baculovirus-expressed VP1 and VP2 & No \\
\hline $\begin{array}{l}\text { Euro immun } \\
\text { (Lubeck Germany) }\end{array}$ & Indirect IgG EIA and class-capture IgM EIA & Yeast-expressed VP2 & No \\
\hline $\begin{array}{l}\text { IBL } \\
\text { (Hamburg, Germany) }\end{array}$ & Indirect IgG and IgM EIA & E. coli-expressed VP1 & No \\
\hline $\begin{array}{l}\text { Focus Parvovirus DxSelect } \\
\text { (Cyprus, CA) }\end{array}$ & Indirect IgG and IgM EIA & Recombinant VP1 & No \\
\hline $\begin{array}{l}\text { Mikrogen } \\
\text { (Martinsried, Germany) }\end{array}$ & $\begin{array}{l}\text { Indirect IgG and IgM EIA and Strip } \\
\text { immunoassay }\end{array}$ & $\begin{array}{l}E \text {. coli-expressed VP1 } \\
\text { baculovirus-expressed VP2 }\end{array}$ & No \\
\hline $\begin{array}{l}\text { Biotrin International } \\
\text { (Dublin Ireland) }\end{array}$ & $\begin{array}{l}\text { Indirect IgG and IgM immunofluorescence } \\
(\text { IFA })^{\mathrm{b}}\end{array}$ & Baculovirus-expressed VP1 & No \\
\hline
\end{tabular}

$\mathrm{VP}^{\mathrm{a}}$ comprises $>95 \%$ of capsid antigen and appears to be conserved among genotypes. ${ }^{\mathrm{b}}$ Pretreatment with adsorbent reagent is needed to prevent interference from rheumatoid factors. ${ }^{\mathrm{C}}$ EIA, enzyme immunoassay; CLIA, chemiluminescence immunoassay. 
IgG negative, the patient is at risk of primary infection and further tests are required if there is a strong clinical suspicion [77].

When only IgG is positive, the doubt may persist if the antibody test was performed at a distance from the clinical point of call or the contact person: if the levels are low and stable, it is certainly an old infection; if the levels are high or have ascending kinetics, it may be a re-infection or a primary infection with IgM that has already disappeared from the serum [78].

\subsection{Viral DNA Detection (PCR)}

PCR techniques to quantify viral DNA are commonly used. The most widely used technique is real-time PCR, which gives very rapid results with very high sensitivity [3].

The search for DNA in maternal blood can sometimes help in diagnosis because PCR is positive in the first month following primary infection; DNA then decreases progressively. This PCR can also be performed on abortion products or fetal tissue taken during an autopsy. A preliminary study has shown that amniotic fluid samples are much richer in virus than maternal blood collected at the same time [79]. In the case of low IgM and viral DNA levels with a strong suspicion of contagion, it is possible to test for antibodies to VP2 and VP1, thus allowing a very early diagnosis of seroconversion and thus the implementation of fetal surveillance [80].

PCR also appears to be of particular interest for the analysis of MFIU in the first and third trimesters of unknown etiology [81] [82] (Table 5).

Table 5. Diagnostic techniques and samples used for diagnosing congenital parvovirus B19 infections [83].

\begin{tabular}{ll}
\hline \multicolumn{1}{c}{ Sample } & \multicolumn{1}{c}{ Technique } \\
\hline Maternal serum & IgG/IgM, ELISA, Western blot, immunofluorescence \\
Maternal serum & In situ hybridization \\
Maternal serum & AFP (Elevated prior to detction of hydrops) \\
Maternal serum & AFP (Elevated) \\
Maternal serum & PCR \\
Maternal serum & IgG antobodies against viral non-stuctural protein NS1 \\
Amniotic fluid & PCR \\
Amniotic fluid & PCR, southern blot, chemiluminescence \\
Amniotic fluid & Enzymatic amplification of parvovirus B19 (segment) \\
Fetal blood & PCR, dot-blot hybridization, in situ hybridization \\
Fetal blood & Enzymatic amplification of parvovirus B19 (segment) \\
Fetal serum & PCR \\
Fetal heart tissue & Microscopy: VP1 and VP2 viral particles \\
Fetal tissues & Microscopy: histology was found to be as sensitive as PCR \\
\hline
\end{tabular}

Ig, immunoglobulin; ELISA, enzyme-linked immunosorbent assay; AFP, alpha-fetoprotein; PCR, polymerase chain reaction (DNA test). 


\subsection{Anatomopathological Analysis}

This analysis allows the detection of intra nuclear viral inclusions and margined chromatin, particularly in erythroid progenitors (lungs, liver, thymus, kidneys, etc.). PVB19 is suspected to cause malformations in the fetus, but very few cases are reported and they only concern spontaneous abortions. Ocular anomalies, myocardial necrosis, and intestinal vascular accidents have been described [84].

\subsection{Ultrasound Examination of the Fetus}

Ultrasound monitoring, by evaluating the degree of hydrops and performing Doppler analysis of the systolic peak of the middle cerebral artery, will allow the severity of fetoplacental hydrops to be assessed. It will make it possible to distinguish between two types of anasarca: early anasarca and pericardial anasarca [85].

\subsection{Antenatal Biological Diagnosis}

Prenatal diagnosis of fetal B19 infection is made by testing for the virus or viral genome in amniotic fluid (PCR) or fetal blood.

B19 infection during pregnancy can affect the fetus and result in hydrops or fetal death. Anasarca is the predominant ultrasound feature in fetuses with parvovirus B19 infection. Obtaining a diagnosis of maternal infection will allow fetal evaluation and treatment by intrauterine blood transfusion. Unfortunately, mothers are often unaware that they have an infection until fetal symptoms are noted. Confirmation of PVB infection 19 requires laboratory analysis, which is complicated by the nature of the viral infection and the immune response [86].

\section{Management of Infection to B19V}

After contact, surveillance at any term is maintained for 12 weeks because there is considered to be a $10 \%$ risk of complications before $28 \mathrm{SA}$ that drops to less than $1 \%$ but still exists after 28SA. A latency of 6 weeks on average between maternal infection and the appearance of fetoplacental anasarca is also noted in the literature [87]. In case of contagion, maternal serology should be checked to determine the initial status and recheck 2 to 3 weeks later (Figure 6).

\section{Prognosis, Prevention and Therapeutic Approaches}

\subsection{Prognosis}

Several studies have shown that the short- and long-term prognosis of children born alive to mothers infected with PVB19 is excellent, with $98 \%$ of children surviving without sequel, even if the mother is infected, in only $17 \%$ to $33 \%$ of cases [55] [89].

The prognosis is clouded by spontaneous abortions and hydrops. The prognosis is clouded by spontaneous abortion and anasarca. Indeed, the prognosis of fetuses in anasarca having been transfused in utero is considered favorable in the light of several studies [90] [91]. 


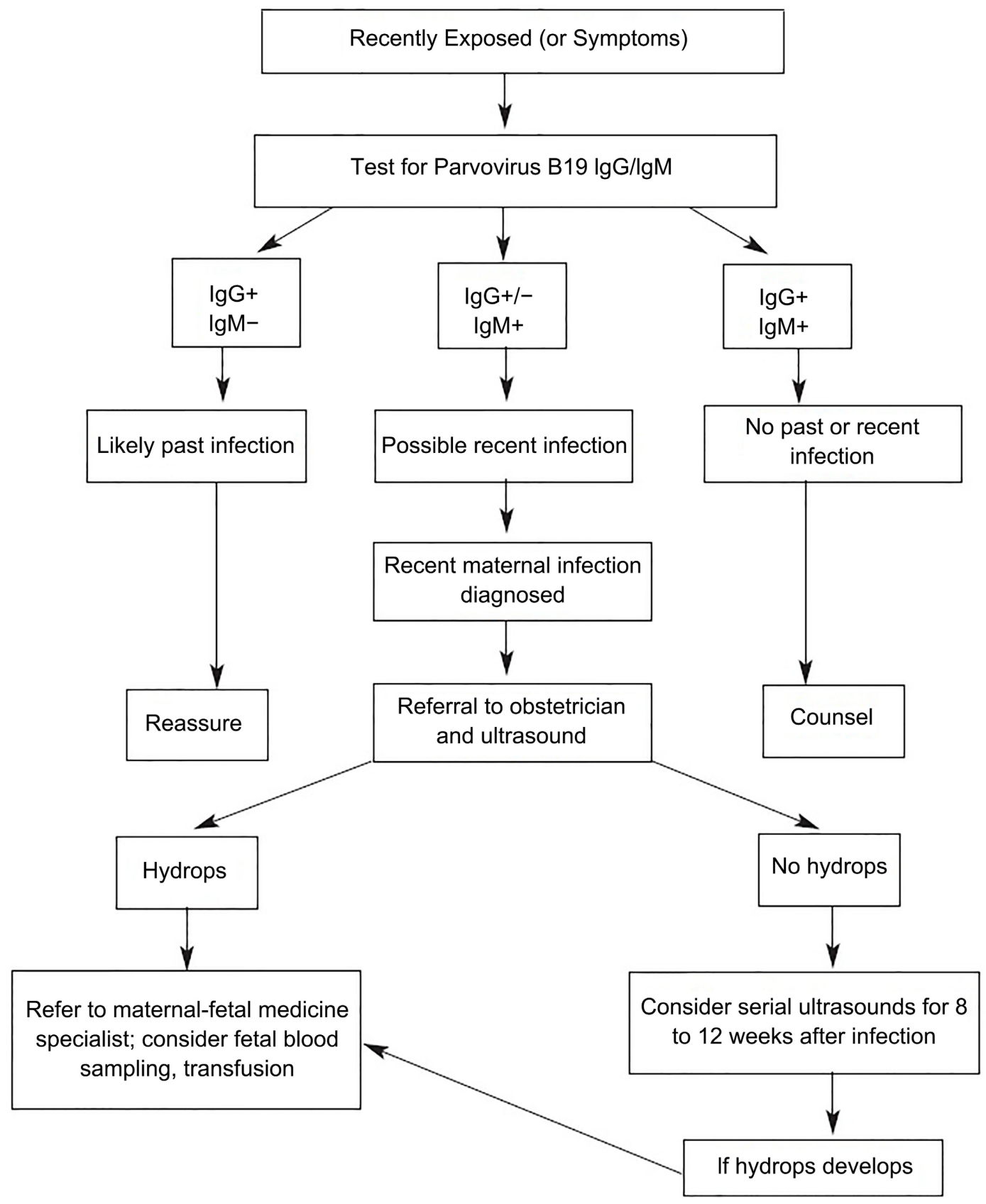

Figure 6. Management of a pregnant woman exposed to parvovirus B19 infection [88].

\subsection{Prevention}

Mothers of young children, as well as women working in schools and daycare centers, are most at risk of exposure to B19 infection. Excluding infected people from the workplace, daycare or school is not likely to prevent the spread because infected people are contagious before symptoms appear [7].

To reduce the risk of infection, pregnant women should:

- Wash their hands thoroughly after touching tissues used by infected children and dispose of tissues immediately.

- Avoid sharing glasses or utensils with anyone who has or has been exposed to 
the disease.

No systematic prevention or screening methods are effective.

\subsection{Therapeutic Approaches}

There is no specific antiviral treatment for PVB19. The primary infection of the immuno competent subject generally does not require any specific treatment. In patients with chronic hemolysis, transfusion of packed blood cells and injection of polyvalent immunoglobulins may be warranted.

Intrauterine blood transfusion has been proposed as treatment for the fetus with severe B19-induced anemia and hydrops. However, the natural history of infection in the untreated fetus is not known, and the benefit of intrauterine blood transfusion is as yet unproven. Several investigators have reported spontaneous resolution of non immune hydrops. A survey of perinatal obstetricians in the United States and Canada reported that $34 \%$ of the cases of non immune hydrops resulting from parvovirus infection resolved spontaneously, the majority within 8 weeks [92]. In the absence of such treatment, fetal death occurs in $90 \%$ of cases [93].

\subsection{B19 Vaccine}

As far as is currently known, no vaccine is currently available. A Phase I study working on a recombinant vaccine comprising the capsid proteins VP1 and VP2 seems to confirm the good immunogenicity of these proteins inducing the production of a high level of antibodies persisting at least one year [94].

\section{Conclusion}

Parvovirus B19 infection is often asymptomatic in adults and children; however, during pregnancy, infection of the fetus may cause transient erythropoietin. If the majority of these attacks are asymptomatic or spontaneously resolved, in a significant percentage of cases, the fetus will be in hydrops and the significant anemia associated with it may benefit from in utero treatment. This will prevent death in utero, as the prognosis of the fetus is in the myocardium and its function. The prognosis of children who have passed the stage of infection in utero is quite favorable.

\section{Conflicts of Interest}

The authors declare no conflicts of interest regarding the publication of this paper.

\section{References}

[1] Cohen, B.J. (1986) Human Parvovirus B19 and Fifth Disease. In: Mortimer, P.P., Ed., Public Health Virology: 12 Reports, Public Health Laboratory Service, London, 130-143.

[2] White, D.G., Woolf, A.D., Mortimer, P.P., Cohen, B.J., Blake, D.R. and Bacon, P.A. (1985) Human Parvovirus Arthropathy. The Lancet, 325, 419-421. 
https://doi.org/10.1016/S0140-6736(85)91145-6

[3] Heegaard, E.D. and Brown, K.E. (2002) Human Parvovirus B19. Clinical Microbiology Reviews, 15, 485-505.

[4] Lunardi, C., Tinazzi, E., Bason, C., et al. (2008) Human Parvovirus B19 Infection and Autoimmunity. Autoimmunity Reviews, 8, 116-120. https://doi.org/10.1016/j.autrev.2008.07.005

[5] Ozawa, K. and Young, N. (1987) Characterisation of Capsid and Non Capsid Proteins of B19 Parvovirus Propagated in Human Erythroid Bone Marrow Cell Cultures. Journal of Virology, 61, 2627-2630.

[6] Committee on Infectious Diseases and American Academy of Pediatrics (2006) Parvovirus B19 (Erythema Infectiosum, Fifth Disease). In: Pickering, L.K., Ed., Red Book 2006: Report of the Committee on Infectious Diseases, American Academy of Pediatrics, Washington DC, 484-487.

[7] Enders, M., Weidner, A., Zoellner, I., et al. (2004) Fetal Morbidity and Mortality after Acute Humane Parvovirus B19 Infection in Pregnancy: Prospective Evaluation of 1018 Cases. Prenatal Diagnosis, 24, 513-518. https://doi.org/10.1002/pd.940

[8] Torok, T.J. (1992) Parvovirus B19 and Human Disease. Advances in Internal Medicine, 37, 431-455.

[9] Brochot, C., Debever, P., Subtil, D. and Puech, F. (2008) Which Supervision and Treatment in Case of Exposure to Parvovirus B19 during Pregnancy? Gynécologie Obstétrique \& Fertilité, 36, 204-211. https://doi.org/10.1016/j.gyobfe.2007.08.028

[10] Xiong, Y.Q., et al. (2019) The Risk of Maternal Parvovirus B19 Infection during Pregnancy on Fetal Loss and Fetal Hydrops: A Systematic Review and Meta-Analysis. Journal of Clinical Virology, 114, 12-20. https://doi.org/10.1016/j.jcv.2019.03.004

[11] Labau, E., Bonnet, E., Alric, L. and Massip, P. (1996) Parvovirus B19 Infection. New Pathophysiological Approaches. La Presse Médicale, 25, 162-166.

[12] Erdman, D.D. (time) Human Parvovirus B19. Laboratory Diagnosis. In: Anderson L.J. and Young, N.S., Eds., Monographs in Virology: Human Parvovirus B19, Karger, Basel, 93-104. https://doi.org/10.1159/000061678

[13] Zerbini, M., Gallinella, G., Cricca, M., Bonvicini, F. and Musiani, M. (2002) Diagnostic Procedures in B19 Infection. Pathologie Biologie, 50, 332-338. https://doi.org/10.1016/S0369-8114(02)00308-5

[14] Cossart, Y., Field, A.M., Cant, B. and Widdows, D. (1975) Parvovirus-Like Particles in Human Sera. The Lancet, 305, 72-73. https://doi.org/10.1016/S0140-6736(75)91074-0

[15] Morinet, F. and Tchernia, G. (1991) Parvovirus B19 and Hematopoiesis. Médecine/Sciences, 7, 127-137. https://doi.org/10.4267/10608/4321

[16] Broliden, K., Tolvenstam, T. and Norbeck, O. (2006) Clinical Aspects of Parvovirus B19 Infection. Journal of Internal Medicine, 260, 285-304. https://doi.org/10.1111/j.1365-2796.2006.01697.x

[17] International Committee on Taxonomy of Viruses (2000) Virus Taxonomy: Classification and Nomenclature of Viruses. Seventh Report of the International Committee on Taxonomy of Viruses. Springer-Verlag, Vienna.

[18] Rogo, L.D., Mokhtari-Azad, T., Kabir, M.H. and Rezaei, F. (2014) Human Parvovirus B19: A Review. ActaVirologica, 58, 199-213.

https://doi.org/10.4149/av 201403199

[19] Kajigaya, S., Fujii, H., Field, A., et al. (1991) Self-Assembled B19 Parvovirus Capsids, Produced in a Baculovirus System, Are Antigenically and Immunogenically 
Similar to Native Virion. Proceedings of the National Academy of Sciences of the United States of America, 88, 4646-4650. https://doi.org/10.1073/pnas.88.11.4646

[20] Schwarz, T.F., Serke, S., Von Brunn, A., et al. (1992) Heat Stability of Parvovirus B19: Kinetics of Inactivation. Zentralblatt für Bakteriologie, 277, 219-223. https://doi.org/10.1016/S0934-8840(11)80616-X

[21] Moffatt, S., Yaegashi, N., Tada, K., Tanaka, N. and Sugamura, K. (1998) Human Parvovirus B19 Nonstructural (NS1) Protein Induces Apoptosis in Erythroid Lineage Cells. Journal of Virology, 72, 3018-3028.

[22] Chen, Z., Guan, W., Cheng, F., Chen, A.Y. and Qiu, J. (2009) Molecular Characterization of Human Parvovirus B19 Genotypes 2 and 3. Virology, 394, 276-285. https://doi.org/10.1016/j.virol.2009.08.044

[23] Guan, W., Cheng, F., Yoto, Y., Kleiboeker, S., Wong, S., Zhi, N., Pintel, D.J. and Qiu, J. (2008) Block to the Production of Full-Length B19 Virus Transcripts by Internal Polyadenylation is Overcome by Replication of the Viral Genome. Journal of Virology, 82, 9951-9963.

[24] Gallinella, G. (2013) Parvovirus B19 Achievements and Challenges. International Scholarly Research Notices, 2013, Article ID: 898730.

https://doi.org/10.5402/2013/898730

[25] Tewary, S.K., Zhao, H., Deng, X., Qiu, J. and Tang, L. (2014) The Human Parvovirus B19 Non-Structural Protein 1 N-Terminal Domain Specifically Binds to the Origin of Replication in the Viral DNA. Virology, 449, 297-303.

https://doi.org/10.1016/j.virol.2013.11.031

[26] Young, N.S. and Brown, K.E. (2004) Parvovirus B19. The New England Journal of Medicine, 350, 586-597. https://doi.org/10.1056/NEJMra030840

[27] Erdman, D.D., Durigon, E.L. and Holloway, B.P. (1994) Detection of Human Parvovirus B19 DNA PCR Products by RNA Probe Hybridization Enzyme Immunoassay. J Clin Microbiol, 32, 2295-2298. https://doi.org/10.1128/jcm.32.9.2295-2298.1994

[28] Gallinella, G., Venturoli, S., Manaresi, E., Musiani, M. and Zerbini, M. (2003) B19 Virus Genome Diversity: Epidemiological and Clinical Correlations. Journal of Clinical Virology, 28, 1-13. https://doi.org/10.1016/S1386-6532(03)00120-3

[29] Eis-Hubinger, A.M., Reber, U., Edelmann, A., Kalus, U. and Hofmann, J. (2014) Parvovirus B19 Genotype 2 in Blood Donations. Transfusion, 54, 1682-1684. https://doi.org/10.1111/trf.12591

[30] Von Kietzell, K., Pozzuto, T., Heilbronn, R., Grössl, T., Fechner, H. and Weger, S. (2014) Antibody-Mediated Enhancement of Parvovirus B19 Uptake into Endothelial Cells Mediated by a Receptor for Complement Factor C1q. Journal of Virology, 88, 8102-8115.

[31] Brown, K.E., Anderson, S.M. and Young, N.S. (1993) Erythrocyte P Antigen: Cellular Receptor for B19 Parvovirus. Science, 262, 114-117. https://doi.org/10.1126/science.8211117

[32] Bültmann, B.D., Klingel, K., Sotlar, K., Bock, C.T. and Kandolf, R. (2003) Parvovirus B19: A Pathogen Responsible for More than Hematologic Disorders. Virchows Archiv, 442, 8-17. https://doi.org/10.1007/s00428-002-0732-8

[33] Koehl, B., Oualha, M., Lesage, F., Rambaud, C., Canioni, D., et al. (2012) Fatal Parvovirus B19 Myocarditis in Children and Possible Dysimmune Mechanism. The Pediatric Infectious Disease Journal, 31, 418-421.

https://doi.org/10.1097/INF.0b013e3182425786 
[34] Peterlana, D., Puccetti, A., Corrocher, R. and Lunardi, C. (2006) Serologic and Molecular Detection of Human Parovirus B19 Infection. Clinica Chimica Acta, 372, 14-23. https://doi.org/10.1016/j.cca.2006.04.018

[35] Anderson, L.J., Tsou, C., Parker, R.A., Chorba, T.L., Wulff, H., Tattersall, P. and Mortimer, P.P. (1986) Detection of Antibodies and Antigens of Human Parvovirus $B 19$ by Enzyme-Linked Immunosorbent Assay. Journal of Clinical Microbiology, 24, 522-526.

[36] Erdman, D.D., Usher, M.J., Tsou, C., Caul, E.O., Gary, G.W., Kajigaya, S., Young, N.S. and Anderson, L.J. (1991) Human Parvovirus B19 Specific IgG, IgA, and IgM Antibodies and DNA in Serum Specimens from Persons with Erythema Infectiosum. Journal of Medical Virology, 35, 110-115.

https://doi.org/10.1002/jmv.1890350207

[37] Anderson, M.J., Higgins, P.G., Davis, L.R., Willman, J.S., Jones, S.E., Kidd, I.M., Pattison, J.R. and Tyrrell, D.A. (1985) Experimental Parvoviral Infection in $\mathrm{Hu}$ mans. The Journal of Infectious Diseases, 152, 257-265. https://doi.org/10.1093/infdis/152.2.257

[38] Magro, C.M., Dawood, M.R. and Crowson, A.N. (2000) The Cutaneous Manifestations of Human Parvovirus B19 Infection. Human Pathology, 31, 488-497. https://doi.org/10.1053/hp.2000.6714

[39] Corman, L.C. and Dolson, D.J. (1992) Polyarteritis Nodosa and Parvovirus B19 Infection. The Lancet, 339, 491. https://doi.org/10.1016/0140-6736(92)91096-Q

[40] Mossong, J., Hens. N., Friederichs, V., Davidkin, I., Broman, M., Litwinska, B., et al. (2008) Parvovirus B19 Infection in Five European Countries: Seroepidemiology, Force of Infection and Maternal Risk of Infection. Epidemiology \& Infection, 136, 1059-1068. https://doi.org/10.1017/S0950268807009661

[41] Ergaz, Z. and Ornoy, A. (2006) Parvovirus B19 in Pregnancy. Reproductive Toxicology, 21, 421-435. https://doi.org/10.1016/j.reprotox.2005.01.006

[42] Dijkmans, A.C., de Jong, E.P., Dijkmans, B.A., Lopriore, E., Vossen, A., Walther, F.J., et al. (2012) Parvovirus B19 in Pregnancy: Prenatal Diagnosis and Management of Fetal Complications. Current Opinion in Obstetrics and Gynecology, 24, 95-101. https://doi.org/10.1097/GCO.0b013e3283505a9d

[43] Lamont, R.F., Sobel, J.D., Vaisbuch, E., Kusanovic, J.P., Mazaki-Tovi, S., Kim, S.K., et al. (2011) Parvovirus B19 Infection in Human Pregnancy. BJOG: An International Journal of Obstetrics \& Gynaecology, 118, 175-186. https://doi.org/10.1111/j.1471-0528.2010.02749.x

[44] Valeur-Jensen, A.K., Pedersen, C.B., Westergaard, T., Jensen, I.P., Lebech, M., Andersen, P.K., et al. (1999) Risk Factors for Parvovirus B19 Infection in Pregnancy. JAMA, 281, 1099-1105. https://doi.org/10.1001/jama.281.12.1099

[45] De Jong, E.P., Walther, F.J., Kroes, A.C. and Oepkes, D. (2011) Parvovirus B19 Infection in Pregnancy: New Insights and Management. Prenatal Diagnosis, 31, 419-425. https://doi.org/10.1002/pd.2714

[46] Chorba, T., Coccia, P., Holman, R.C., Tattersall, P., Anderson, L.J., Sudman, J., et al. (1986) The Role of Parvovirus B19 in Aplastic Crisis and Erythema Infectiosum (Fifth Disease). The Journal of Infectious Diseases, 154, 383-393. https://doi.org/10.1093/infdis/154.3.383

[47] Rodis, J.F., Hovick, T.J., Quinn, D.L., Rosengren, S.S. and Tattersall, P. (1988) Human Parvovirus Infection in Pregnancy. Obstetrics \& Gynecology, 72, 733-738.

[48] Jensen, I.P., Thorsen, P., Jeune, B., Moller, B.R. and Vestergaard, B.F. (2000) An 
Epidemic of Parvovirus B19 in a Population of 3,596 Pregnant Women: A Study of Sociodemographic and Medical Risk Factors. BJOG: An International Journal of Obstetrics \& Gynaecology, 107, 637-643. https://doi.org/10.1111/j.1471-0528.2000.tb13306.x

[49] Koch, W.C., Harger, J.H., Barnstein, B. and Adler, S.P. (1998) Serologic and Virolologic Evidence for Frequent Intrauterine Transmission of Human Parvovirus B19 with a Primary Maternal Infection during Pregnancy. The Pediatric Infectious Disease Journal, 17, 489-494. https://doi.org/10.1097/00006454-199806000-00011

[50] Bonvicini, F., Bua, G. and Gallinella, G. (2017) Parvovirus B19 Infection in Pregnancy-Awareness and Opportunities. Current Opinion in Virology, 27, 8-14. https://doi.org/10.1016/j.coviro.2017.10.003

[51] Brown, K.E. (2005) Parvovirus B19. In: Mandell, G.L., Bennett, J.E. and Dolin, R., Eds., Mandell, Douglas, and Bennett's Principals and Pratice of Infectious Diseases, Churchil Livingstone Elsevier, Philadelphia, 1981-1902.

[52] Brown, T., Anand, A., Ritchie, L.D., et al. (1984) Intrauterine Parvovirus Infection Associated with Hydrops Fetalis. The Lancet, 324, 1033-1034.

https://doi.org/10.1016/S0140-6736(84)91126-7

[53] Chisaka, H., Ito, K., Niikura, H., Sugawara, J., Takano, T., Murakami, T., Terada, Y., Okamura, K., Shiroishi, H., Sugamura, K. and Yaegashi, N. (2006) Clinical Manifestations and Outcomes of Parvovirus B19 Infection during Pregnancy in Japan. Tohoku. Journal of Experimental Medicine, 209, 277-283.

[54] Bonvicini, F., Puccetti, C., Nunzio, C., Salfi, M., Guerra, B., Gallinella, G., Rizzo, N. and Zerbini, M. (2011) Gestational and Fetal Outcomes in B19 Maternal Infection: A Problem of Diagnosis. Journal of Clinical Microbiology, 49, 3514-3518. https://doi.org/10.1128/JCM.00854-11

[55] Miller, E., Fairley, C.K., Cohen, B.J. and Seng, C. (1998) Immediate and Long Term Outcome of Human Parvovirus B19 Infection in Pregnancy. BJOG: An International Journal of Obstetrics \& Gynaecology, 105, 174-178.

https://doi.org/10.1111/j.1471-0528.1998.tb10048.x

[56] Enders, M., Klingel, K., Weidner, A., Baisch, C., Kandolf, R., Schalasta, G. and Enders, G. (2010) Risk of Fetal Hydrops and Non-Hydropic Late Intrauterine Fetal Death after Gestational Parvovirus B19 Infection. Journal of Clinical Virology, 49, 163-168. https://doi.org/10.1016/j.jcv.2010.07.014

[57] Macé, G., Sauvan, M., Castaigne, V., Moutard, M.L., Cortey, A., Maisonneuve, E., Garel, C., Dhombres, F. and Boujenah, J. (2014) Clinical Presentation and Outcome of 20 Fetuses with Parvovirus B19 Infection Complicated by Severe Anemia and/or Fetal Hydrops. Prenatal Diagnosis, 34, 1023-1030. https://doi.org/10.1002/pd.4413

[58] Morinet, F., Pallier, C. and Pillet, S. (2003) Parvoviridae. In: Huraux, J.M., Nicolas, J.C., Augut, H. and Peigue-Lafeuille, H., Eds., Traité de virologie médicale, Société française de microbiologie, Paris, 283-289.

[59] Nabae, K., Satoh, H., Nishiura, H., Tanaka-Taya, K., Okabe, N., Oishi, K., Matsumoto, K. and Hasegawa, T. (2014) Estimating the Risk of Parvovirus B19 Infection in Blood Donors and Pregnant Women in Japan. PloS ONE, 9, e92519. https://doi.org/10.1371/journal.pone.0092519

[60] Habibzadeh, S., Peeri-Doghaheh, H., Jafar, M.S., Elham, M. and Shahbazzadegan, S. (2016) The Prevalence of Parvovirus B19 Infection among Pregnant Women of Ardabil in 2013. Iranian Journal of Microbiology, 8, 214-218.

[61] Khameneh, Z.R., Hanifian, H., Barzegari, R. and Sepehrvand, N. (2014) Human 
Parvovirus B19 in Iranian Pregnant Women: A Serologic Survey. Indian Journal of Pathology and Microbiology, 57, 442-444. https://doi.org/10.4103/0377-4929.138748

[62] Mirambo, M.M., Maliki, F., Majigo, M., Mushi, M.F., Moremi, N., Seni, J., Matovelo, D. and Mshana, S.E. (2017) The Magnitude and Correlates of Parvovirus B19 Infection among Pregnant Women Attending Antenatal Clinics in Mwanza, Tanzania. BMC Pregnancy and Childbirth, 17, Article No. 176. https://doi.org/10.1186/s12884-017-1364-y

[63] Abiodun, L., Opaleye, O.O., Ojurongbe, O. and Fagbami, A.H. (2013) Seroprevalence of Parvovirus B19 IgG and IgM Antibodies among Pregnant Women in Oyo State, Nigeria. The Journal of Infection in Developing Countries, 7, 946-950.

[64] Gasim, G.I., Eltayeb, R., Elhassan, E.M., Haggaz, A.D., Rayis, D.A. and Adam, I. (2016) Human Parvovirus B19 and Low Hemoglobin Levels in Pregnant Sudanese Women. International Journal of Gynecology \& Obstetrics, 132, 318-320. https://doi.org/10.1016/j.ijgo.2015.07.027

[65] Hannachi, N., Marzouk, M., Harrabi, I., Ferjani, A., Ksouri, Z., Ghannem, H., Khairi, H., Hidar, S. and Boukadida, J. (2011) Seroprevalence of Rubella Virus, Varicella Zoster Virus, Cytomegalovirus and Parvovirus B19 among Pregnant Women in the Sousse Region, Tunisia. Bulletin de la Société de Pathologie Exotique, 104, 62-67. https://doi.org/10.1007/s13149-010-0119-Z

[66] Pedranti, M.S., Adamo, M.P., Macedo, R. and Zapata, M.T. (2007) Prevalence of Anti-Rubella and Anti-Parvovirus B19 Antibodies in Pregnant Women in the City of Córdoba, and in Women of Fertile Age in the City of Villa Mercedes, Province of San Luis. Revista Argentina de Microbiología, 39, 47-50.

[67] Elnifro, E., Nisha, A.K., Almabsoot, M., Daeki, A., Mujber, N. and Muscat, J. (2009) Seroprevalence of Parvovirus B19 among Pregnant Women in Tripoli, Libya. The Journal of Infection in Developing Countries, 3, 218-220.

[68] Zajkowska, A., Garkowski, A., Czupryna, P., Moniuszko, A., Król, M.E., Szamatowicz, J. and Pancewicz, S. (2015) Seroprevalence of Parvovirus B19 Antibodies among Young Pregnant Women or Planning Pregnancy, Tested for Toxoplasmosis. Przegląd Epidemiologiczny, 69, 479-482.

[69] Adam, O., Makkawi, T., Reber, U., Kirberg, H. and Eis-Hübinger, A.M. (2015) The Seroprevalence of Parvovirus B19 Infection in Pregnant Women in Sudan. Epidemiology and Infection, 143, 242-248. https://doi.org/10.1017/S0950268814000600

[70] Zavattoni, M., Paolucci, S., Sarasini, A., Tassis, B., Rustico, M., Quarenghi, A., Piralla, A. and Baldanti, F. (2016) Diagnostic and Prognostic Value of Molecular and Serological Investigation of Human Parvovirus B19 Infection during Pregnancy. New Microbiologica, 39, 181-185.

[71] Makhseed, M., Pacsa, A., Ahmed, M.A. and Essa, S.S. (1999) Pattern of Parvovirus B 9 Infection During Different Trimesters of Pregnancy in Kuwait. Infectious Diseases in Obstetrics and Gynecology, 7, 287-292. https://doi.org/10.1002/(SICI)1098-0997(1999)7:6<287::AID-IDOG7>3.0.CO;2-M

[72] Barlinna, R., Rollagb, H., Trogstada, L., Vainioa, K., Basseta, C., Magnusc, P. and Dudmana, S.G. (2017) High Incidence of Maternal Parvovirus B19 Infection in a Large Unselected Population-Based Pregnancy Cohort in Norway. Journal of Clinical Virology, 94, 57-62. https://doi.org/10.1016/j.jcv.2017.07.010

[73] van Gessel, P.H., Gaytant, M.A., Vossen, A.C.T.M., Galama, J.M.D., Ursem, N.T.C., Steegers, E.A.P. and Wildschut, H.I.J. (2006) Incidence of Parvovirus B19 Infection among an Unselected Population of Pregnant Women in the Netherlands: A Pros- 
pective Study. European Journal of Obstetrics \& Gynecology and Reproductive Biology, 128, 46-49. https://doi.org/10.1016/j.ejogrb.2005.11.042

[74] Gallinella, G. (2017) Molecular Testing for Parvovirus. In: Coleman, W.B. and Tsongalis, G.J., Eds., Diagnostic Molecular Patholog, Academic Press, Cambridge, 103-113. https://doi.org/10.1016/B978-0-12-800886-7.00009-1

[75] Ferguson, M. and Heath, A. (2004) Report of a Collaborative Study to Calibrate the Second International Standard for Parvovirus B19 Antibody. Biologicals, 32, 207-212. https://doi.org/10.1016/j.biologicals.2004.09.004

[76] Landry, M.L. (2015) Parvovirus B19. Microbilogy Spectrum, 4, DMIH2-0008.

[77] Crane, J., et al. (2002) Infection au Parvovirus B19 Encours de Grossesse. JSOGS, 119.

[78] De Jong, E.P., et al. (2006) Parvovirus B19 Infection in Pregnancy. Journal of Clinical Virology, 36, 1-7. https://doi.org/10.1016/j.jcv.2006.01.004

[79] Knoll, A., Louwen, F., Kochanauski, B., Plentz, A., Stussel, J., Beckenlehner, K., Jilg, W. and Modrow, S. (2002) Parvovirus B19 Infection in Pregnancy: Quantitative Viral ADN Analysis Using a Kinetic Flurescence Detection System (TaqMan PCR). Journal of Medical Virology, 67, 259-266. https://doi.org/10.1002/jmv.2216

[80] Enders, M., Schalasta, G., Baisch, C., et al. (2006) Human Parvovirus B19 Infection during Pregnancy-Value of Modern Molecular and Serological Diagnostics. Journal of Clinical Virology, 35, 400-406. https://doi.org/10.1016/j.jcv.2005.11.002

[81] Tolfvenstam, T., Papadogiannakis, N., Norbeck, O., Petersson, K. and Broliden, K. (2001) Frequency of Human Parvovirus B19 Infection in Intrauterine Fetal Death. The Lancet, 357, 1494-1497. https://doi.org/10.1016/S0140-6736(00)04647-X

[82] Skjoldebrand-Sparre, L., Tolfvenstam, T., Papadogiannakis, N., Wahren, B., Broliden, K. and Nyman, M. (2000) Parvovirus B19 Infection: Association with Third Trimester Intrauterine Fetal Death. BJOG: An International Journal of Obstetrics \& Gynaecology, 107, 476-480. https://doi.org/10.1111/j.1471-0528.2000.tb13265.x

[83] Von Kaisenberg, C. S. and Jonat, W. (2001) Fetal Parvovirus B19 Infection. Ultrasound in Obstetrics \& Gynecology, 18, 280-288.

https://doi.org/10.1046/j.1469-0705.2001.00471.x

[84] Brown, K.E. (1998) What Threat Is Human Parvovirus B19 to the Fetus? BJOG: An International Journal of Obstetrics \& Gynaecology, 96, 764-767.

https://doi.org/10.1111/j.1471-0528.1989.tb03313.x

[85] Benoist, G., Dina, J. and Herlicoviez, M. (2011) Chapitre 32-Parvovirus B19 et grossesse. In: Sentilhes, L. and Bonneau, D., Eds., Le diagnostic prénatal en pratique, Elsevier Masson, Paris, 339-344.

https://doi.org/10.1016/B978-2-294-70962-3.00032-X

[86] Crane, J., Mundle, W. and Boucoiran, I. (2014) Infection au Parvovirus B19 pendant la grossesse. Journal of Obstetrics and Gynaecology Canada, 36, 1117-1118. https://doi.org/10.1016/S1701-2163(15)30391-1

[87] Subtil, D., Garabedian, C. and Chauvet, A. (2015) Infection à Parvovirus B19 et grossesse. La Presse Médicale, 44, 647-653. https://doi.org/10.1016/j.lpm.2015.04.013

[88] Faden, Y. (2007) Toxoplasmosis, Cytomegalovirus, Herpes Simplex Virus, Rubella, Parvovirus, and Listeria Infections. In: Lee, R., Keely, E. and Rosella-Montella, K., Eds., Medical Care of the Pregnant Patien, American College of Physicians, Philadelphia, 687-708. 
[89] Gratacos, E., et al. (1995) The Incidence of Human Parvovirus B19 Infection during Pregnancy and Its Impact on Perinatal Outcome. The Journal of Infectious Diseases, 171, 1360-1363. https://doi.org/10.1093/infdis/171.5.1360

[90] Dembinski, J., Haverkamp, F., Maara, H., Hansmann, M., Eis-Hubinger, A.M. and Bartmann, P. (2002) Neurodevelopmental Outcome after Intrauterine Red Cell Transfusion for Parvovirus B19-Induced Fetal Hydrops. BJOG: An International Journal of Obstetrics \& Gynaecology, 109, 1232-1234.

https://doi.org/10.1046/j.1471-0528.2002.02118.x

[91] Vanspranghels, R., Houfflin-Debarge, V., Vaast, P., Coulon, C., Clouqueur, E., Hanssens, S., Rakza, T., Subtil, D. and Garabedian, C. (2019) Does an Intrauterine Exchange Transfusion Improve the Fetal Prognosis in Parvovirus Infection Cases? Transfusion, 59, 185-190. https://doi.org/10.1111/trf.14968

[92] Rodis, J.F., Borgida, A.F., Wilson, M., Egan, J.F.X., Leo, M.V., Odibo, A.O., et al. (1998) Management of Parvovirus Infection in Pregnancy and Outcomes of Hydrops: A Survey of Members of the Society of Perinatal Obstetricians. American Journal of Obstetrics and Gynecology, 179, 985-988. https://doi.org/10.1016/S0002-9378(98)70203-0

[93] Bousquet, F., Segondy, M., Faure, J.M., Deschamps, F. and Boulot, P. (2000) B19 Parvovirus Induced Fetal Hydrops: Good Outcome after Intrauterine Blood Transfusion at 18 Weeks of Gestation. Fetal Diagnosis and Therapy, 15, 132-133. https://doi.org/10.1159/000020991

[94] Ballou, W.R., Reed, J.L., Noble, W., Young, N.S. and Koenig, S. (2003) Safety and Immunogenicity of a Recombinant Parvovirus B19 Vaccine Formulated with MF59C. 1. The Journal of Infectious Diseases, 187, 675-678. https://doi.org/10.1086/368382 